\title{
Ore Texture, Mineralogy and Whole Rock Geochemistry of the Iron Mineralization from Edea North Area, Nyong Complex, Southern Cameroon: Implication for Origin and Enrichment Process
}

\author{
Bravo Martin Mbang Bonda1, Jacques Etame ${ }^{*}$, Arnaud Patrice Kouske ${ }^{2}$, Elie Constantin Bayiga1, \\ Gilbert François Ngon Ngon'1, Simon Joel Mbaï1, Martine Gérard ${ }^{3}$ \\ ${ }^{1}$ Department of Earth Sciences, Faculty of Science, University of Douala, Douala, Cameroon \\ ${ }^{2}$ Department of Civil Engineering, The University Institute of Technology, University of Douala, Douala, Cameroon \\ ${ }^{3}$ IRD, UMR 161 CEREGE, Institut de minéralogie et physique des milieux condensés, Paris, France \\ Email: *etame.jacques@yahoo.fr
}

How to cite this paper: Bonda, B.M.M. Etame, J., Kouske, A.P., Bayiga, E.C., Ngon, G.F.N. Mbaï, S.J. and Gérard, M. (2017) Edea North Area, Nyong Complex, Southern Cameroon: Implication for Origin and Enrichment Process. International Journal of Geosciences, 8, 659-677.

https://doi.org/10.4236/ijg.2017.85036

Received: February 21, 2017

Accepted: May 15, 2017

Published: May 18, 2017

Copyright $\odot 2017$ by authors and Scientific Research Publishing Inc. This work is licensed under the Creative Commons Attribution International License (CC BY 4.0).

http://creativecommons.org/licenses/by/4.0/

\section{Abstract}

This study presents the ore texture, mineralogy and whole rock geochemistry of iron occurrence from the Edea North area located at the upper limit of the Nyong Unit, part of the Congo craton. This iron mineralization is of magnetite quartzite type enclosed by metamorphic rocks of the granulite facies. Two main facies have been identified over the study area including the banded and the massive facies. The mineralogical set of these facies is in majority represented by magnetite, quartz and pyroxene martite in addition to minor biotite, apatite, and amphibole. Magnetite presents as irregular and elongated minerals which can contain quartz inclusions of various shapes and sizes, as blasts clustering, around pyroxenes and isolated xenomorphic magnetite minerals in the silicate phases. Quartz varies from fine to coarse-grained and ribbon quartz. This indicates re-crystallization and deformation during metamorphism. Electron microprobe analysis on magnetite and martite show $\mathrm{Fe}_{2} \mathrm{O}_{3}$ contents that vary between 96.11 and 99.76 . Whole rock chemical data showed that $\mathrm{Fe}$-contents are as high as $62.9 \mathrm{wt} \%$. The $\mathrm{SiO}_{2}$ content varies between $33.8 \mathrm{wt} \%$ and $51.2 \mathrm{wt} \%$. Iron oxides and $\mathrm{SiO}_{2}$ are negatively correlated. Moreover, the low positive correlations between $\mathrm{Al}_{2} \mathrm{O}_{3}$ and HFSE, and LILE suggest a contribution of clastic materials in the protolith of studied materials. The samples show low contents of $\mathrm{V}, \mathrm{Cr}, \mathrm{Ba}, \mathrm{Zr}$ with respect to igneous rocks. This may infer a sedimentary origin for the studied rocks; furthermore, these materials may have undergone hydrothermal alteration. The REE patterns re- 
veal enrichment in LREE compared to HREE. Some samples show positive Eu (1.82) and other negative anomalies Eu (0.54 to 0.97). The lack of Ce anomalies suggests that the depositional environment of the Edea North iron occurrence was anoxic or suboxic. Overall, the Edea North iron occurrence may have undergone significant input from hydrothermal sources with imprints of the clastic during its deposition.

\section{Keywords}

Magnetite, Texture, Edea North, Nyong Complex, Southern Cameroon

\section{Introduction}

Low iron commodity prices since January 2014 acted for low expenditure on iron exploration and dearth of discoveries of new iron deposits around the world. However, iron, being a raw material of steel, is a key issue for the growing global steel industry. Thus, despite the current low price of iron, the long-term trend for iron is positive. Classically, there are two types of Precambrian iron formations discriminated based on their depositional setting: 1) Algoma-type iron formations are in close proximity to ancient volcanic centers suggesting a sub-aqueous hydrothermal origin similar to modern day sea-floor spreading centers [1]; 2) the Lake Superior-type BIFs are developed in passive-margin sedimentary rock successions and generally lack direct relationships with extrusive volcanic materials and are therefore interpreted as chemical precipitates of iron-rich waters in a shallow sea [2]. Recently, [3] have proposed the composition-based definition of Fe-formations as "siliceous and Fe-rich sedimentary chemical precipitates with low levels of detrital siliciclastic or volcaniclastic material $\left(<1 \% \mathrm{Al}_{2} \mathrm{O}_{3}\right)$ and greater than $10 \%$ total $\mathrm{Fe}$, regardless of whether $\mathrm{Fe}$ is associated with a carbonate or oxide phase". This definition of Fe formation encompasses both granular and banded Fe formations as well as ferruginous cherts (e.g. distal hydrothermal jaspers). Moreover, the quality of iron ore is a key issue in the steel industry. The increasing global demand for iron, however, has made BIF-hosted low grade iron ore ( $\mathrm{Fe}<40 \mathrm{wt} . \%)$ important targets for exploration. In addition to the increasing scarcity of economic hematite deposits worldwide lead magnetite to emerge as an important source of the world's iron.

Although Cameroun is not yet an iron producer, past works and particularly within the ongoing decade have led to the discovery in Precambrian greenstones terrain of south Cameroon, of several BIF-hosted iron deposits including Mbalam [4] [5] [6] [7], Nkout [8] [9], Bikoula (www.aluvance.com), Elom [10], and Zambi deposits [11] and Kouambo deposit [12]. Most of these studies have used BIF to infer the origin and depositional environment of these iron formations. Although the BIFs are less widely distributed than other lithologies (e.g., Archean TTG), they are an integral and unique part of the Ntem Complex which corresponds to the northern edge of the Congo craton [12]. However, BIF are 
not the only iron formation in this complex. Recent works by the "Compagnie Minière du Cameroun" (CMC) (see www.africaminerals.com) have evidenced magnetite gneisses with estimated reserves of 10 millions of tons in the Edéa North iron, within the Nyong unit which is part of the Archaean Ntem complex. However, no scientific work on these formations is available in the literature.

The present work was conducted at the time of renewed interest in the iron ore potential of the Edéa North iron ore project. This article presents ore texture, mineralogy and whole rock geochemistry of the Edéa North iron occurrence with the aim at characterizing these iron-formations as well as to infer their enrichment processes.

\section{Geological Setting}

The Archean Ntem Complex greenstones belt is located within the northern margin of the Congo craton in Cameroon [13] [14] [15]. This complex is made up of Archean and Palaeoproterozoic rocks and constitutes a relative stable block limited in the north by the Pan-African orogenic belt (e.g. Yaounde Group) [16] [17]. The Ntem Complex greenstones belt trends E-W and extends over $500 \mathrm{~km}$ from Mbalam in the South East to Kribi in Atlantic cost in the West. This belt has been subdivided into three main units including the Ayna Unit, the Ntem Unit and the Nyong Unit respectively from the East to the West. The Ntem complex was affected by two major periods of deformation. The first involves successive diapiric emplacements of the Mesoarchean charnockites $(\sim 2.900 \mathrm{Ma})$ and TTGs ( 2830 Ma). It is marked by vertical foliation and lineation, stretching and isoclinal folds [18]. This episode of deformation was synchronous with a regional granulite-facies metamorphism [19]. This Archean event was followed, in the Paleoproterozoic, by a trans-current deformation phase marked by the development of N-S to NE-SW trending sinistral shear zones and partial melting of the TTG suite and the greenstone belt country rocks, with generation of a variety of granites [20]. Late syenitic plutons ( 2.3 $\mathrm{Ga}$ ) intruded the complex during this second tectonic episode [21]. The Eburnean metamorphism affected all the Archean and Paleoproterozoic formations and was dated at $\sim 2.05 \mathrm{Ga}$ [22]. The Edea North area is located at the upper limit of the Nyong Unit (Figure 1(a)). This Unit is dominated by biotitehornblende gneisses, which locally appear as grey gneisses of TTG composition, orthopyroxene-garnet gneisses (charnockites), garnet amphibole-pyroxenites, and banded iron-formation [11] [13] [23] [24]. This Unit is of Mesoarchaen to Palaeoproterozoic [23], and belongs to the West Central African Belt (WCAB) [25] [26]. The study site is composed of the charnockitic suit rocks, orthogneisses, mylonites and magnetite gneisses (Figure 1(b)).

\section{Sampling and Analytical Methods}

A total of 8 iron mineralization sample were selected on the base of their massive appearance and magnetic properties and prepared for microscopic petrography and geochemical analyses. Polished thin sections were prepared at the "Laboratoire 

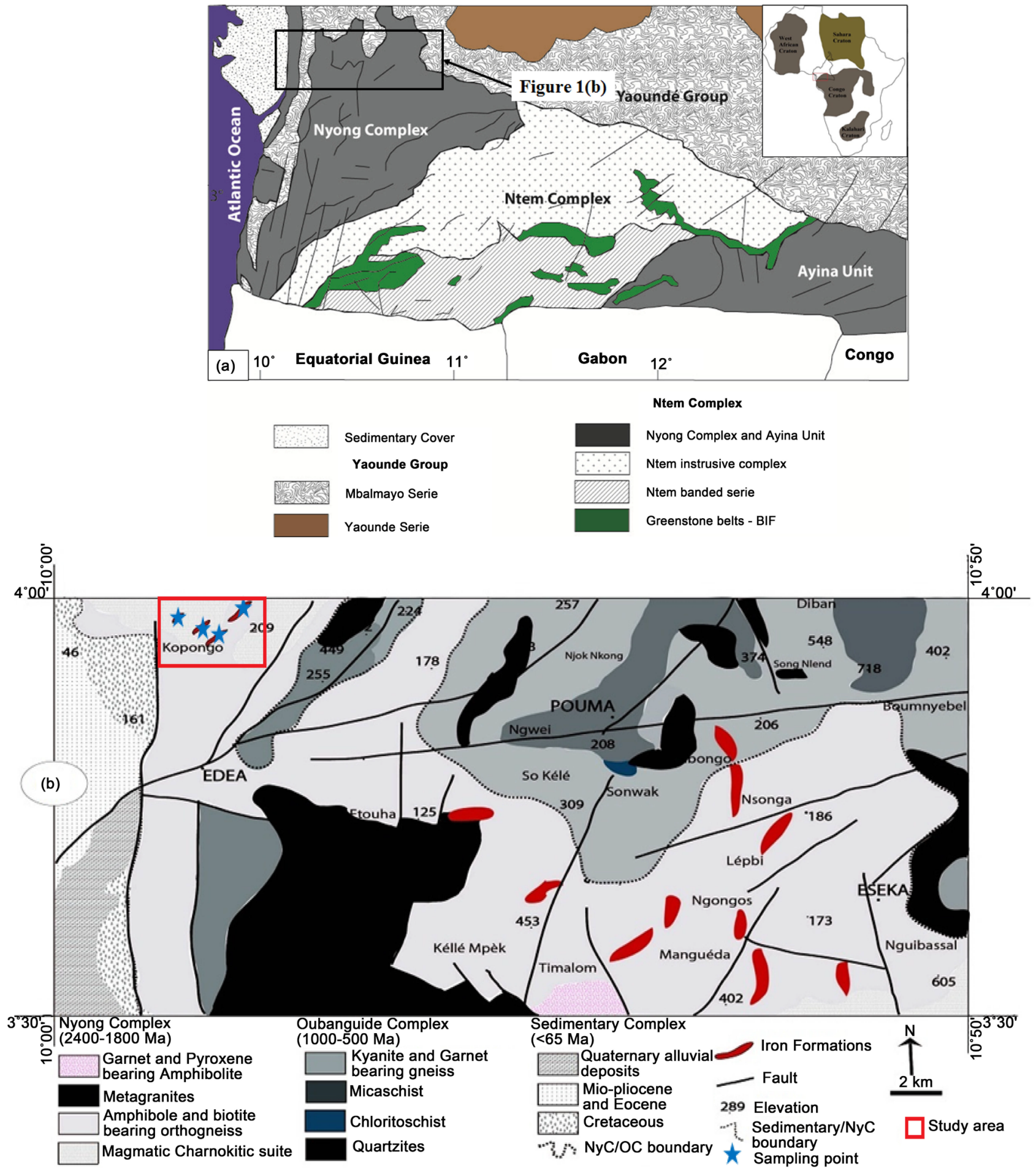

Figure 1. Location of study area. (a) Simplified geological map of South-West Cameroun [13]; (b) Geological map of Edea-Eseka modified after [27].

de propriétés des amorphes, liquides et minéraux de l'institut de physique des matériaux et de cosmochimie de l'Université de Pierre et Marie Curie (France)" for petrography and EMPA. EMPA on iron minerals was achieved in the up-mentioned laboratory. The samples were analyzed for $\mathrm{Al}_{2} \mathrm{O}_{3}, \mathrm{Fe}_{2} \mathrm{O}_{3}, \mathrm{SiO}_{2}$, $\mathrm{TiO}_{2}, \mathrm{Cr}_{2} \mathrm{O}_{3}$ and $\mathrm{MnO}$ using and acceleration voltage of $15 \mathrm{KeV}$ and a beam cur- 
rent of $150 \mathrm{nA}$. Natural and artificial silicates and oxides were used as standards. The detection limit was set at $0.01 \mathrm{wt} \%$ for the entire major elements and relative measurement errors not exceed 1\%. Petrographic observations of the polished sections was done using both transmitted and reflected light at the Economic Geology Unit laboratory, University of Buea, Cameroon. Whole rock geochemical analyses were performed at ALS Minerals Global Group in South Africa and Canada using Inductively Coupled Plasma-Atomic Emission Spectrometry (ICP-AES) for major elements and Inductively Coupled Plasma-Mass Spectrometry (ICP-MS) for trace and Rare Earth Elements. During analysis, $0.2 \mathrm{~g}$ of the rock powder was fused with lithium or lithium metaborate/tetraborate $\left(\mathrm{LiBO}_{2}\right)$ and dissolve in nitric acid $\left(\mathrm{HNO}_{3}\right)$. Loss on ignition (LOI) was determined by firing the powder at $1000^{\circ} \mathrm{C}$ and calculating the weight difference before and after the firing. In order to maintain the data quality, various standards and unknowns were run between the analyses.

\section{Results}

\subsection{Textures and Ore Mineralogy}

Hand specimens of iron mineralization samples from the Edea North were divided into two main facies based on their physical appearance: the banded and the massive ore (Figure 2). Bands in the banded facies are irregular and discontinuous there are made up of thin bands of ferromagnesian minerals which alternate with silica-rich microbands and the contact banding is not sharp (Figure 2(a)). Some of the studied samples displayed a trellis-like structure (Figure 3). Microscopic examinations of these samples have confirmed the irregularity of the bands. The mineralogy of the banded samples consists of iron minerals (75\%), pyroxenes (25\%) in the ferromagnesian bands and quartz (80\%), and dominating silica-rich bands. The mineralogical composition of the massive ore includes iron minerals (45\%), quartz (30\%) and pyroxene (16\%) with minor, ilmenite $(1 \%)$, biotite $(0.5 \%)$, apatite $(0.5 \%)$ and amphiboles $(1 \%)$. The reflected light microscopic observations revealed that the iron minerals phase is dominated by magnetite in both facies and to a lesser amount martite. All the pyro-
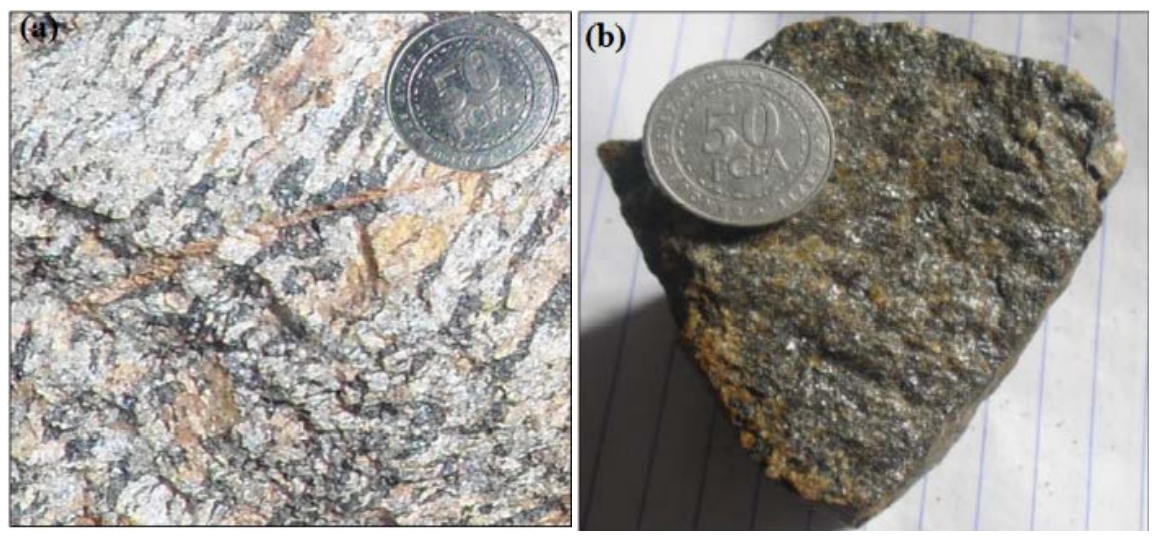

Figure 2. Representative iron ores from Edea North iron mineralization. (a) Banded facies. Note the irregular band (b) Massive ore facies. 

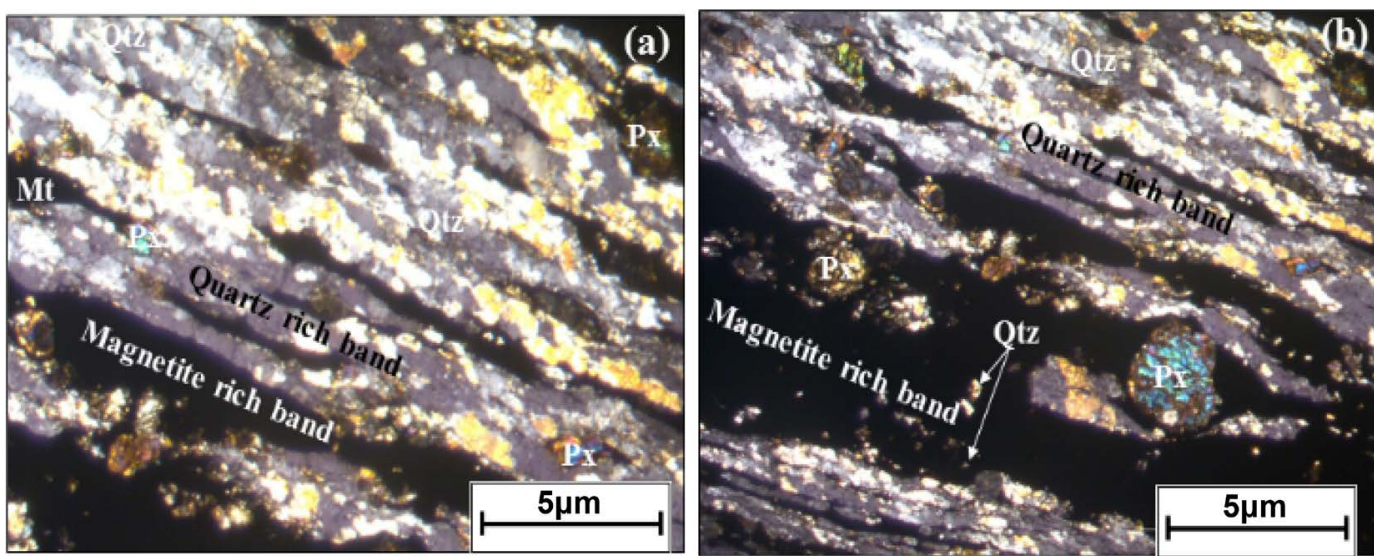

Figure 3. Representative photomicrographs of iron ores from the Edea north. A weak banding with alternating magnetite and quartz bands can be identified. (a) Discontinuous magnetite bands with quartz inclusions. (b) The embedded pyroxene as inclusion in magnetite ribbon. $\mathrm{Mt}=$ magnetite, $\mathrm{Qtz}=$ quartz, $\mathrm{Px}$ = pyroxene.

xenes minerals present marks of alteration and some of them are deformed within the bands (Figure 3(b)).

Magnetite in the both facies occurs as in various shapes: as irregular and elongated minerals can contain quartz inclusions of various shapes and sizes (Figure 3(a)). Magnetite also appears as cluster around pyroxenes and embedded at their limits, thus forming haloes and rolls (Figure 4(c) and Figure 4(d)). Finally magnetite occurs as disseminations in quartz matrix (Figure 4(c) and Figure 4(d)). Martite results from the alteration of magnetite is altered to martite (Figure 5) and rare inclusions of ilmenite occur within. Martite is euhedral to subhedral and it is commonly observed at the crystal interface of magnetite and silicate strip.

Quartz is the main gangue mineral identified. It displays three textural varieties including fine-grained, coarse-grained and ribbon quartz (Figure 3 and Figure 4). It occurs in band or as inclusions in magnetite or pyroxene. In addition, quartz shows a characteristic undulating texture (Figure 4(b)). The observed crystals are fractured, xenomorphic and subhedral to anhedral phases.

The pyroxenes occur as inclusions in both silica and magnetite. They are subhedral, yellow-orange, and riding in thin strips of magnetite forming rolls (Figure 3(b)) and always close or in the iron mineral phase.

Amphiboles are sometimes green xenomorphic crystals with quartz inclusions.

\subsection{Mineral and Whole Rock Geochemistry}

Electron microprobe analysis revealed that $\mathrm{Fe}_{2} \mathrm{O}_{3(\mathrm{~T})}$ contents range from $97.12 \%$ to $99.76 \%$ and between $96.11 \%$ and $97 \%$ respectively on magnetite and martite (Table 1). All other major oxides occur in low quantities except $\mathrm{Al}_{2} \mathrm{O}_{3}$ with contents as high as $2.65 \%$.

The chemical composition of iron ore from the Edea North area is summarized in Table 2. The samples show $\mathrm{SiO}_{2}$ contents that range from 33.8 to 51.2 

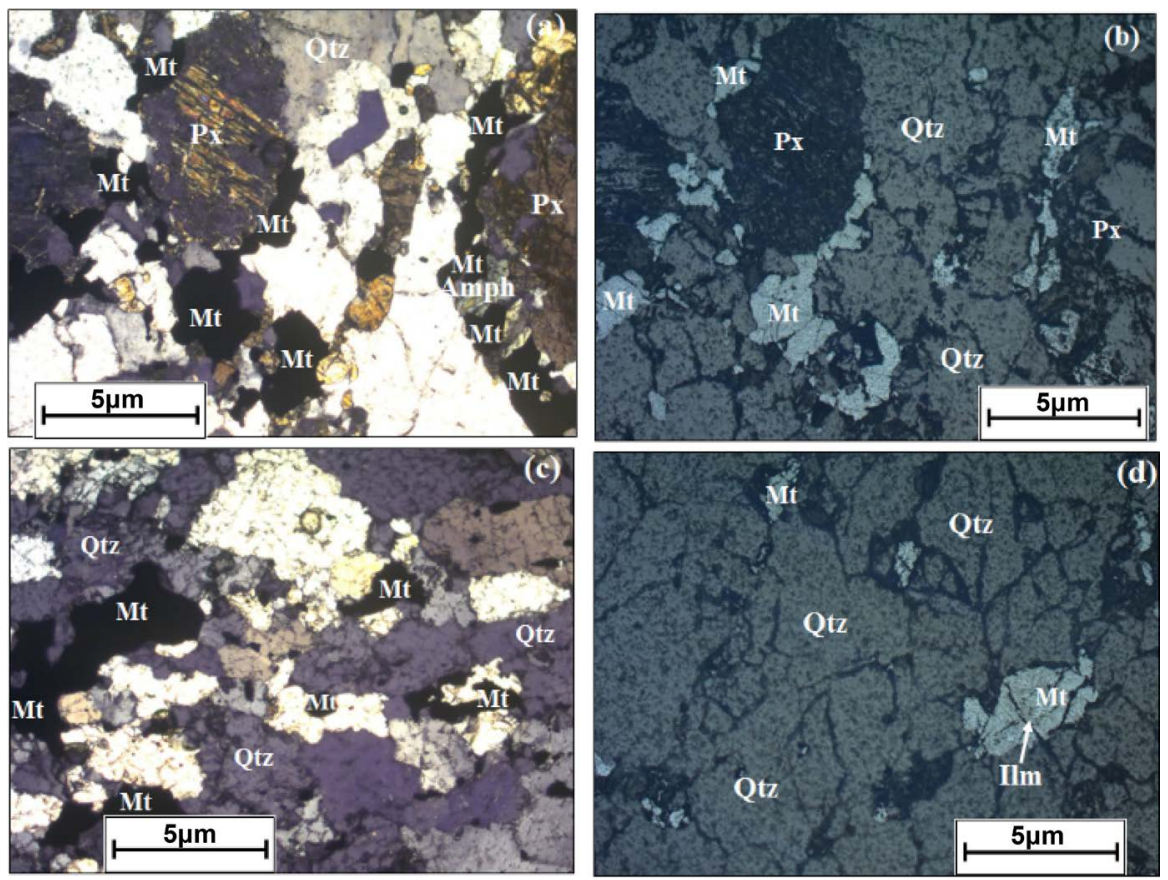

Figure 4. Representative polarized and reflected ((c), (d)) light photomicrographs and showing the various magnetite grained texture identified in the Edea north iron mineralization. (a) and (b) Magnetite cluster texture around pyroxene, (b) and (c) Magnetite isolated crystals textures. Note the undulating and coarse-grained textures of quartz. Mt: magnetite; Mrt: martite; Amph: Amphibole; Px: pyroxene; Qtz: quartz; Ilm: Ilmenite.
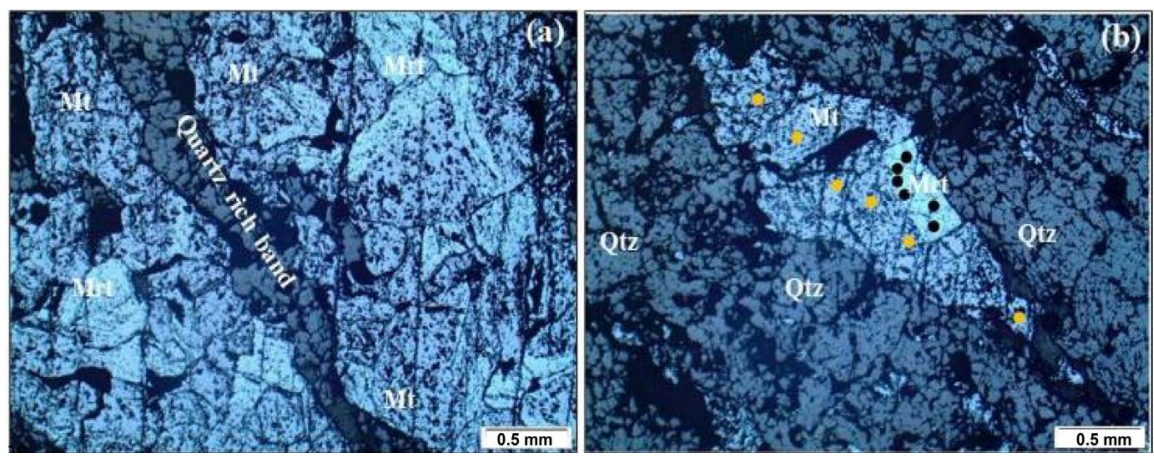

Figure 5. Representative reflected light photomicrographs showing the martite minerals in the iron mineralization in the Edea north iron occurrence. The yellow and black circle represents the EPMA analysis point on Magnetite and Martite respectively.

$\mathrm{wt} \%$ and $\mathrm{Fe}_{2} \mathrm{O}_{3}$ contents that vary between 40.4 and $62.9 \mathrm{wt} \%$ respectively. There is a very strong negative correlation $\left(R^{2}=-0.92\right)$ between these two oxides (Table 3). Concentrations of $\mathrm{Al}_{2} \mathrm{O}_{3}$ vary between $0.46 \%$ and $4.19 \%$ (with an average of $1.40 \%)$ and $\mathrm{P}_{2} \mathrm{O}_{5}$ concentrations are generally low $(0.01 \%-0.15 \%)$. The other major oxides have relatively low contents: $\mathrm{CaO}(0.01 \%-0.47 \%), \mathrm{K}_{2} \mathrm{O}$ $(0.01 \%-0.02 \%), \mathrm{Na}_{2} \mathrm{O}(0.01 \%-0.08 \%)$ and $\mathrm{MnO}(0.01 \%-0.09 \%)$. there is a positive correlation $\left(\mathrm{R}^{2}=0.89\right)$ between $\mathrm{Al}_{2} \mathrm{O}_{3}$ and $\mathrm{TiO}_{2}$ while $\mathrm{Al}_{2} \mathrm{O}_{3}$ and $\mathrm{Fe}_{2} \mathrm{O}_{3}$ are negatively correlated $\left(\mathrm{R}^{2}=-0.60\right)$ (Table 3$)$.

Trace elements are weakly concentrated in the studied samples. The High Field Strength Elements (HFSE), Hf, Zr, Th and U vary from $0.2-0.4$ ppm, 7 - 
37 ppm, 0.19 - 15.5 ppm and 0.09 - 0.72 ppm respectively (Table 2). The contents of Large Ion Lithophile Elements (LILE), Sr, Rb, and Ba vary from 1 to 27.3 ppm, 0.2 to $1.7 \mathrm{ppm}$ and 1.6 to $131 \mathrm{ppm}$ respectively. The studied iron ore are depleted in HFSE and LILE when compare to the upper continental crust after [28].

Rare earth elements concentration in the iron ore from the Edea North area vary with $\Sigma$ REE oscillating between 5.31 and $397.74 \mathrm{ppm}$ (average of 80.41) (Table 2). The samples are enriched in Light Rare Earth Elements (LREE) compared to Heavy Rare Earth Elements (HREE) with LREE/HREE ratios between 10.35 and 55.61 (average of 24.37) (Figure 6). The samples show a negative Eu anomaly (Eu/Eu* between 0.54 and 0.97) except EDN19 and EDN17 that reveal a slightly positive $\mathrm{Eu}$ anomaly (Eu/Eu* values range from 1 to 1.83$)$. Ce displays negative anomalies between 0.39 and 0.87 . The majority of the samples showed a negative anomaly in $\mathrm{La}$ and none in $\mathrm{Ce}$ and one sample displayed a positive anomaly in Ce (Figure 7).

\section{Discussion}

\subsection{Mineralogical Association and Nature of the Edea North Iron Occurrence}

Petrographic examination of the studied samples shows the following mineral assemblage: Magnetite + Quartz + Pyroxene \pm Biotite \pm Martite \pm Amphibole This mineralogy is characteristic of iron formations that have undergone metamorphism in the granulite facies [29]. Quartz and magnetite-martite identified in the samples is consistent with the geochemistry that shows $\mathrm{Fe}_{2} \mathrm{O}_{3}$ contents from 40.4 wt $\%$ to 62.9 wt $\%$ and $\mathrm{SiO}_{2}$ contents between $33.8 \mathrm{wt} \%$ and $51.2 \mathrm{wt} \%$.

Table 1. Electron microprobe analyses on magnetite and martite from the Edéa North iron mineralization.

\begin{tabular}{|c|c|c|c|c|c|c|c|c|}
\hline Minerals & Data set/point & $\mathrm{Al}_{2} \mathrm{O}_{3}$ & $\mathrm{SiO}_{2}$ & $\mathrm{TiO}_{2}$ & $\mathrm{Cr}_{2} \mathrm{O}_{3}$ & $\mathrm{MnO}$ & $\mathrm{Fe}_{2} \mathrm{O}_{3}$ & Total \\
\hline \multirow[t]{6}{*}{ Magnetite } & 1 & 0.25 & 0.02 & 0.05 & bdl & 0.08 & 99.30 & 99.70 \\
\hline & 2 & 0.17 & bdl & 0.03 & bdl & 0.05 & 99.76 & 100.00 \\
\hline & 3 & 0.20 & 0.03 & 0.06 & bdl & 0.05 & 99.67 & 100.00 \\
\hline & 4 & 2.65 & 0.02 & 0.20 & 0.001 & 0.02 & 97.12 & 100.00 \\
\hline & 5 & 0.17 & 0.02 & 0.03 & bdl & 0.05 & 99.72 & 100.00 \\
\hline & 6 & 0.94 & 0.02 & 0.15 & 0.001 & 0.06 & 98.83 & 100.00 \\
\hline \multirow[t]{6}{*}{ Martite } & 1 & 0.17 & 0.03 & 0.03 & bdl & 0.04 & 96.11 & 96.38 \\
\hline & 2 & 0.15 & 0.02 & 0.02 & bdl & 0.06 & 96.38 & 96.61 \\
\hline & 3 & 0.16 & 0.02 & 0.03 & 0.00 & 0.05 & 96.94 & 97.20 \\
\hline & 4 & 0.20 & 0.05 & 0.03 & 0.00 & 0.08 & 96.75 & 97.10 \\
\hline & 5 & 0.17 & 0.02 & 0.02 & 0.00 & 0.05 & 97.00 & 97.26 \\
\hline & 6 & 0.17 & 0.01 & 0.02 & bdl & 0.05 & 96.24 & 96.48 \\
\hline
\end{tabular}

bdl $=$ below detection limit 
B. M. M. Bonda et al.

Table 2. Whole rock major, trace and rare earth element composition of samples of the iron mineralization from the Edea north, southern Cameroon.

\begin{tabular}{|c|c|c|c|c|c|c|c|c|c|}
\hline \multirow{2}{*}{ Sample ID } & \multicolumn{4}{|c|}{ Banded iron ore facies } & \multicolumn{4}{|c|}{ Massive iron ore facies } & \multirow{2}{*}{ Avg. } \\
\hline & EDN04 & EDN 12 & EDN18 & EDN19 & EDN09 & EDN14 & EDN15 & EDN17 & \\
\hline $\mathrm{SiO}_{2}(\mathrm{wt} \%)$ & 44.1 & 42.8 & 35.4 & 48.1 & 45.9 & 51.2 & 35.1 & 33.8 & 42.05 \\
\hline $\mathrm{TiO}_{2}$ & 0.1 & 0.16 & 0.11 & 0.06 & 0.05 & 0.36 & 0.06 & 0.35 & 0.16 \\
\hline $\mathrm{Al}_{2} \mathrm{O}_{3}$ & 0.47 & 1.38 & 1.29 & 0.64 & 0.63 & 4.19 & 0.46 & 2.14 & 1.4 \\
\hline $\mathrm{Fe}_{2} \mathrm{O}_{3}$ & 55 & 54.7 & 59.8 & 53.3 & 52 & 40.4 & 62.6 & 62.9 & 55.09 \\
\hline $\mathrm{MnO}$ & 0.03 & 0.02 & 0.01 & 0.04 & 0.08 & 0.09 & 0.02 & 0.03 & 0.04 \\
\hline $\mathrm{MgO}$ & 0.14 & 0.02 & 0.03 & 0.02 & 1.3 & 1.58 & 0.04 & 0.46 & 0.45 \\
\hline $\mathrm{CaO}$ & 0.03 & 0.01 & 0.01 & 0.01 & 0.2 & 0.47 & 0.01 & 0.2 & 0.12 \\
\hline $\mathrm{Na}_{2} \mathrm{O}$ & 0.01 & 0.01 & 0.01 & 0.01 & 0.02 & 0.08 & 0.01 & 0.01 & 0.02 \\
\hline $\mathrm{K}_{2} \mathrm{O}$ & 0.01 & 0.01 & 0.01 & 0.01 & 0.02 & 0.01 & 0.01 & 0.01 & 0.01 \\
\hline $\mathrm{P}_{2} \mathrm{O}_{5}$ & 0.05 & 0.06 & 0.06 & 0.01 & 0.11 & 0.11 & 0.06 & 0.15 & 0.08 \\
\hline LOI & 0.59 & 0.77 & 1.68 & -0.65 & -1.24 & 2.15 & 1.5 & 0.1 & 0.61 \\
\hline Total & 100.53 & 99.94 & 98.41 & 101.55 & 99.07 & 100.64 & 99.87 & 100.15 & 100.02 \\
\hline $\mathrm{V}(\mathrm{ppm})$ & 7 & 13 & 22 & 9 & 5 & 69 & 8 & 31 & 24.00 \\
\hline $\mathrm{Cr}$ & 20 & 30 & 20 & 10 & 30 & 80 & 40 & 10 & 31.67 \\
\hline Cs & 0.02 & 0.01 & 0.1 & 0.11 & 0.04 & 0.16 & $<0.01$ & 0.26 & 0.13 \\
\hline $\mathrm{Rb}$ & 0.5 & 0.5 & $<0.2$ & $<0.2$ & 0.6 & 0.7 & $<0.2$ & 1.7 & 1.00 \\
\hline $\mathrm{Sr}$ & 2.1 & 12.6 & 3.9 & 2.2 & 5 & 27.3 & 1 & 11.6 & 8.50 \\
\hline $\mathrm{Y}$ & 1.9 & 5 & 2.8 & $<0.5$ & 3.8 & 109.5 & 1.2 & 8.2 & 25.10 \\
\hline $\mathrm{Zr}$ & 10 & 13 & 11 & 14 & 8 & 37 & 11 & 7 & 14.67 \\
\hline $\mathrm{Ba}$ & 6.1 & 74.9 & 39 & 2.2 & 12.7 & 131 & 1.6 & 120.5 & 51.17 \\
\hline Th & 0.31 & 1.79 & 0.39 & 0.19 & 1.27 & 0.24 & 1.57 & 15.5 & 3.19 \\
\hline $\mathrm{U}$ & 0.11 & 0.72 & 0.09 & 0.15 & 0.64 & 0.18 & 0.25 & 0.53 & 0.31 \\
\hline $\mathrm{Ta}$ & 0.1 & 0.3 & 0.5 & 0.6 & 0.1 & 0.6 & 0.2 & 0.5 & 0.42 \\
\hline $\mathrm{Nb}$ & 1.3 & 4.1 & 1.8 & 6.3 & 1.7 & 4.2 & 1.8 & 6.1 & 3.65 \\
\hline $\mathrm{Ga}$ & 6.5 & 12.4 & 6.4 & 8.5 & 4.9 & 11.7 & 3.1 & 25.2 & 9.97 \\
\hline $\mathrm{Hf}$ & 0.3 & 0.4 & 0.3 & 0.3 & 0.2 & 1.1 & 0.3 & 0.2 & 0.40 \\
\hline Sn & 2 & 8 & 1 & 5 & 4 & 7 & 2 & 6 & 4.17 \\
\hline $\mathrm{W}$ & $<1$ & 1 & 1 & $<1$ & 1 & $<1$ & $<1$ & 1 & 1.00 \\
\hline $\mathrm{Th} / \mathrm{U}$ & 2.82 & 2.49 & 4.33 & 1.27 & 1.98 & 1.33 & 6.28 & 29.25 & 7.41 \\
\hline $\mathrm{La}$ & 2.9 & 5.2 & 2.9 & 0.7 & 4.9 & 46.9 & 0.9 & 53.1 & 18.23 \\
\hline $\mathrm{Ce}$ & 5.4 & 11.7 & 5.7 & 1.3 & 10.8 & 160 & 2 & 39.6 & 36.57 \\
\hline $\operatorname{Pr}$ & 0.73 & 1.45 & 0.76 & 0.11 & 1.2 & 17.7 & 0.24 & 10.4 & 5.07 \\
\hline $\mathrm{Nd}$ & 2.5 & 6.3 & 3 & 0.6 & 4.8 & 77.8 & 1 & 33.7 & 20.15 \\
\hline $\mathrm{Sm}$ & 0.48 & 1.44 & 0.45 & 0.09 & 0.87 & 20.3 & 0.23 & 6.23 & 4.70 \\
\hline $\mathrm{Eu}$ & 0.08 & 0.25 & 0.17 & 0.04 & 0.22 & 4.21 & 0.05 & 1.57 & 1.04 \\
\hline Gd & 0.42 & 1.3 & 0.73 & 0.05 & 0.89 & 19.55 & 0.23 & 3.72 & 4.20 \\
\hline $\mathrm{Tb}$ & 0.05 & 0.17 & 0.06 & 0.01 & 0.1 & 3.17 & 0.03 & 0.48 & 0.64 \\
\hline Dy & 0.39 & 0.9 & 0.47 & 0.05 & 0.61 & 19.5 & 0.23 & 2.62 & 3.91 \\
\hline
\end{tabular}




\section{Continued}

\begin{tabular}{cccccccccc}
\hline Ho & 0.08 & 0.17 & 0.08 & 0.01 & 0.12 & 3.94 & 0.05 & 0.44 & 0.77 \\
$\mathrm{Er}$ & 0.2 & 0.38 & 0.39 & 0.05 & 0.33 & 11.45 & 0.15 & 0.99 & 2.23 \\
$\mathrm{Tm}$ & 0.02 & 0.04 & 0.06 & 0.01 & 0.06 & 1.55 & 0.01 & 0.2 & 0.32 \\
$\mathrm{Yb}$ & 0.18 & 0.19 & 0.23 & 0.03 & 0.3 & 10.2 & 0.17 & 0.71 & 1.94 \\
$\mathrm{Lu}$ & 0.03 & 0.03 & 0.05 & 0.01 & 0.04 & 1.47 & 0.02 & 0.12 & 0.29 \\
$\mathrm{LREE}$ & 13.46 & 29.52 & 15.05 & 3.06 & 25.24 & 397.74 & 5.31 & 153.88 & 100.05 \\
$\mathrm{LREE}$ & 11.53 & 24.65 & 12.36 & 2.71 & 21.7 & 302.4 & 4.14 & 136.8 & 80.02 \\
$\mathrm{HREE}$ & 0.51 & 0.81 & 0.81 & 0.11 & 0.85 & 28.61 & 0.4 & 2.46 & 5.54 \\
$\mathrm{LREE} / \mathrm{HREE}$ & 22.61 & 30.43 & 15.26 & 24.64 & 25.53 & 10.57 & 10.35 & 55.61 & 23.66 \\
$(\mathrm{La} / \mathrm{Yb})_{\mathrm{CN}}$ & 10.04 & 17.99 & 6.02 & 7.27 & 12.72 & 3.31 & 4.67 & 45.94 & 13.32 \\
$\left(\mathrm{Y} / \mathrm{Y}^{*}\right)_{\mathrm{CN}}$ & 1.04 & 1.05 & 0.68 & 0.72 & 0.97 & 0.95 & 0.97 & 0.99 & 0.88 \\
$(\mathrm{Eu} / \mathrm{Eu})_{\mathrm{CN}}$ & 0.54 & 0.56 & 0.91 & 1.82 & 0.76 & 0.65 & 0.66 & 1.00 & 0.97 \\
$(\mathrm{Ce} / \mathrm{Ce})_{\mathrm{CN}}$ & 0.87 & 1.00 & 0.90 & 1.10 & 1.04 & 1.30 & 1.01 & 0.39 & 0.96 \\
\hline
\end{tabular}

$(\mathrm{Eu} / \mathrm{Eu} *)_{\mathrm{CN}}=\left(\frac{E u}{\sqrt{S m^{*} G d}}\right)_{\mathrm{CN}} ;(\mathrm{Ce} / \mathrm{Ce})_{\mathrm{CN}}=\left(\frac{C e}{\sqrt{L a^{*} \mathrm{Pr}}}\right)_{\mathrm{CN}} ;\left(\mathrm{Y} / \mathrm{Y}^{*}\right)=\left(\frac{Y}{\sqrt{D y^{*} H o}}\right)_{\mathrm{CN}}$

Table 3. Linear inter-elements correlations $\left(R^{2}\right)$ for all iron mineralization samples $(n=8)$.

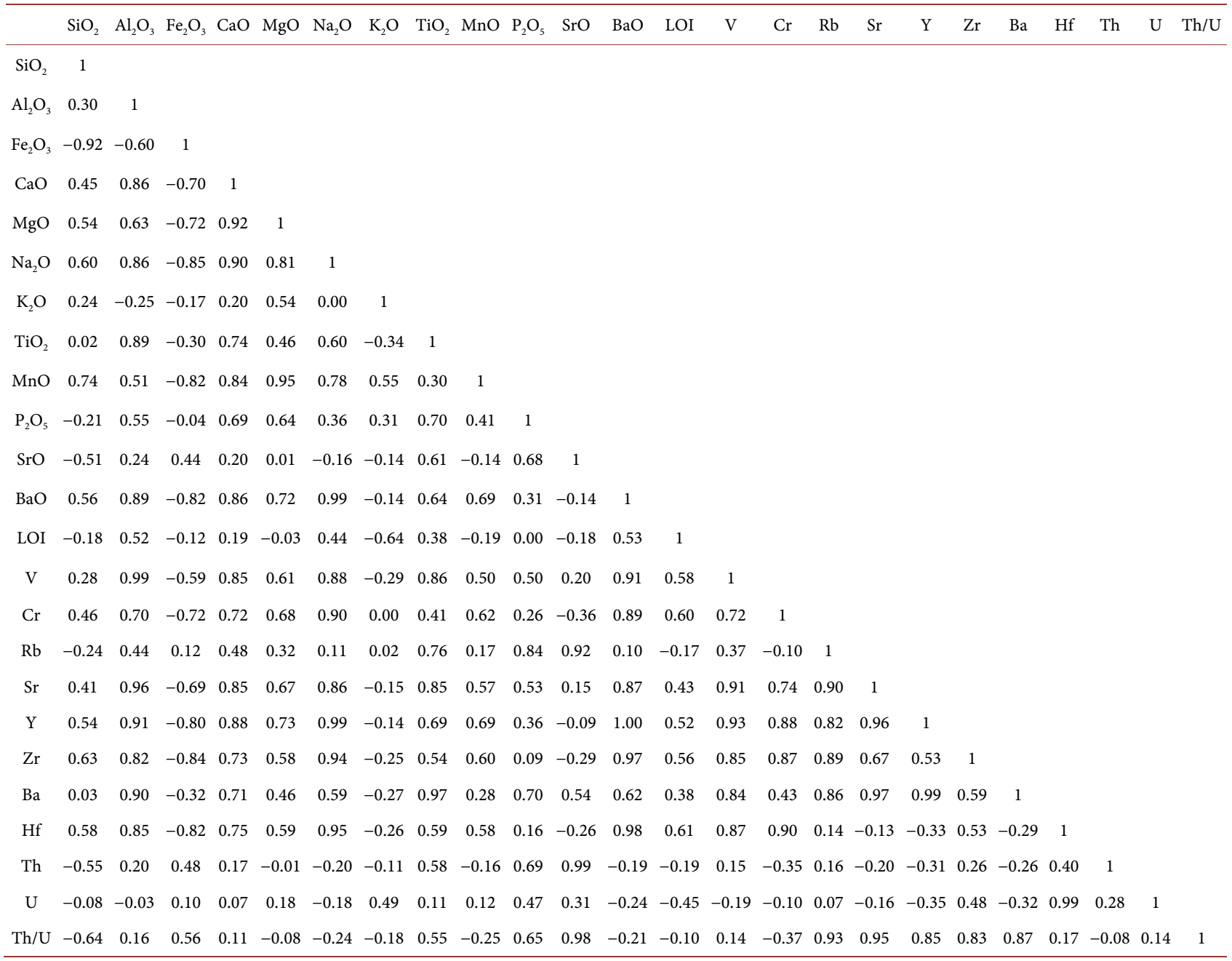




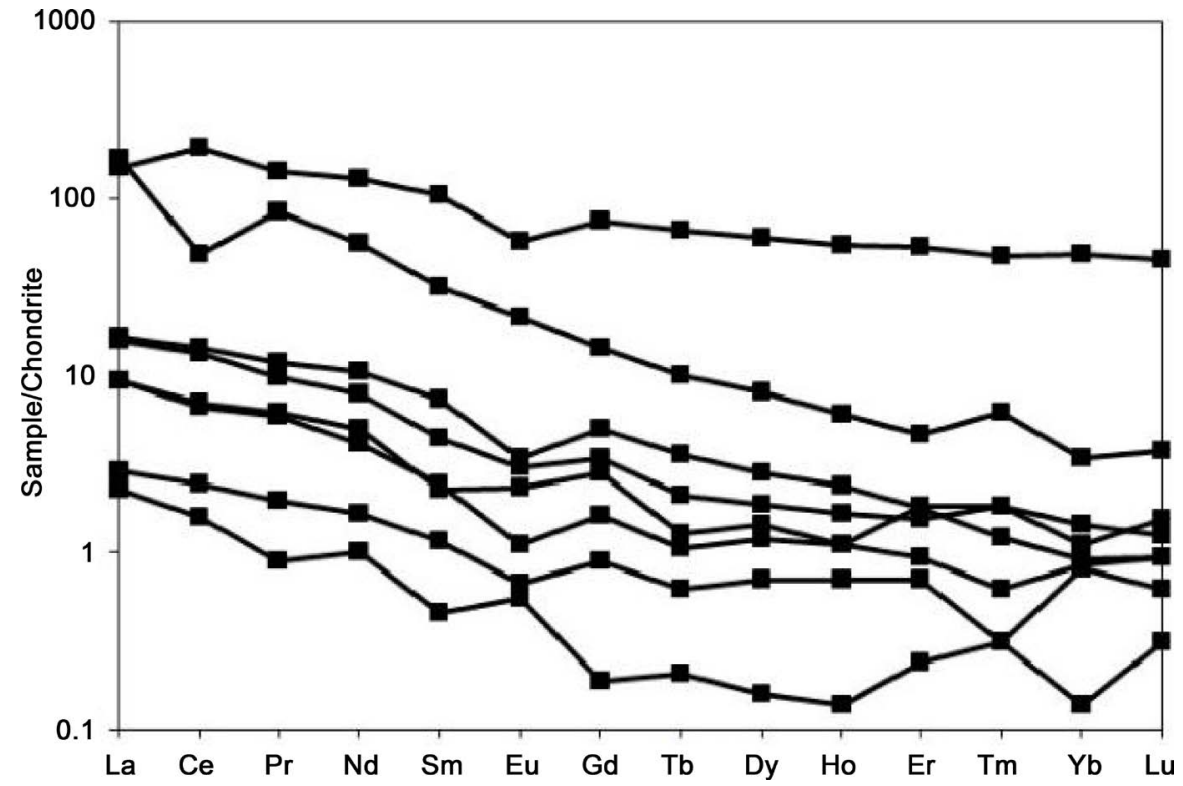

Figure 6. REE pattern of iron ore from the Edea north iron occurrence normalized with chondrite. Normalization values of chondrite after [28]. Samples are enriched in LREE compare depleted in HREE. There are also showing Eu anomalies that vary between negative and positive. Ce negative anomaly is conceding in one sample.

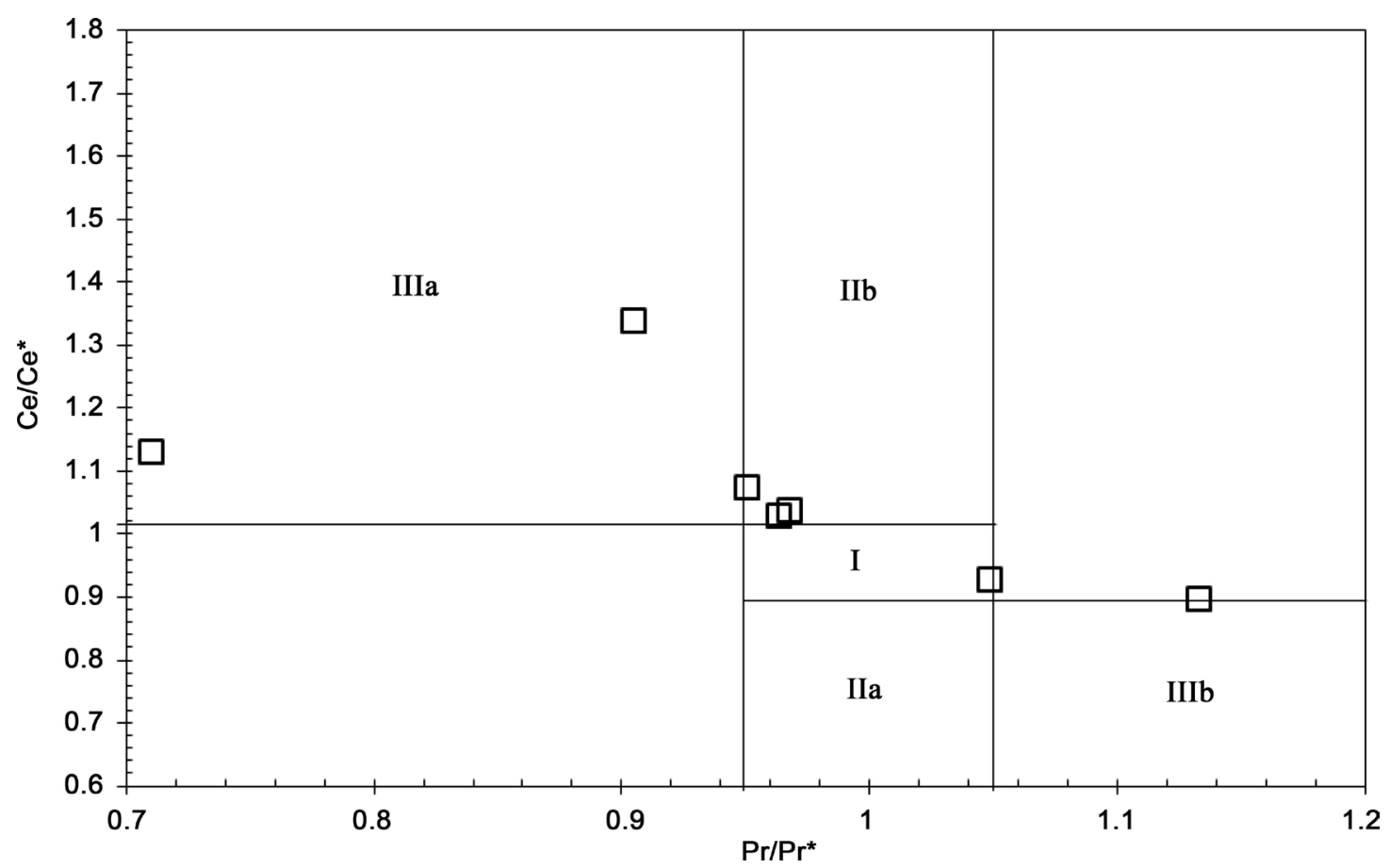

Figure 7. $\left(\mathrm{Ce} / \mathrm{Ce}^{\star}\right)_{\mathrm{CN}} \mathrm{VS}\left(\mathrm{Pr} / \mathrm{Pr}^{*}\right)_{\mathrm{CN}}$ diagram (after [43]) for iron occurrence of the Edea North. Field I: neither Ce nor La anomaly; field IIa: positive La anomaly, no Ce anomaly; field IIb: negative La anomaly, no Ce anomaly; field IIIa: positive Ce anomaly; field IIIb: negative Ce anomaly.

Two main facies have been identified in the Edea North iron occurrence including the banded facies showing discontinuous banding and the massive facies. Based on the physical appearance and the chemical composition of the studied rocks, the name quartzite rich magnetite-martite has been proposed for this iron 
formation.

The Precambrian iron formations have low $\mathrm{Al}_{2} \mathrm{O}_{3}, \mathrm{TiO}_{2}, \mathrm{P}_{2} \mathrm{O}_{5}, \mathrm{CaO}$ and $\mathrm{MgO}$ contents relative to post-Precambrian deposits [30] [31]. On a $\mathrm{Fe}_{2} \mathrm{O}_{3}-\mathrm{CaO}+$ $\mathrm{MgO}-\mathrm{SiO}_{2}$ [30] and $\mathrm{Al}_{2} \mathrm{O}_{3}-\mathrm{SiO}_{2}-\mathrm{Fe}_{2} \mathrm{O}_{3}$ [31] ternary diagrams, studied materials indicates a Precambrian affinity (Figure 8).

\subsection{Textural Characterization of Magnetite}

In the studied iron formations, magnetite presents irregular and elongated minerals which can contain quartz inclusions of various shapes and sizes. In addition to this textural observation, magnetite is deformed and may derive from chemical precipitations thus indicating a primary crystallization of magnetite [32]. The second magnetite texture is in the form of blasts clustering, around pyroxenes. It suggests a secondary crystallization resulting from the probable transformation of pyroxenes. Finally, xenomorphic magnetite crystals isolated in the silicate phases, which suggest the precipitation of magnetite during the formation of this occurrence. On the other hand, the relationships between magnetite and martite suggest the transformation of the first into the second during supergene enrichment. Overall, the following mineral transformation is suggested here: pyroxene-magnetite-martite.

\subsection{Contribution of Detrital Materials}

The participation of the detrital materials during the formation of iron mineralization has been highlighted in the literature. In the BIF, the contribution of detrital materials is generally indicated by the high concentrations of $\mathrm{Al}_{2} \mathrm{O}_{3}, \mathrm{TiO}_{2}$ and High Field Strength Elements (HFSE) (Zr, Hf, Ta, Th ...) and also by the inter-elements correlations between HFSE and rare earth ratios [10] [33]. The geochemical data of the Edea North iron occurrence are summarized in Table 2. High $\mathrm{SiO}_{2}$ and $\mathrm{Fe}_{2} \mathrm{O}_{3}$ contents indicate chemical precipitation. In addition, [34] estimates that a typical chemical sediment is enriched in $\mathrm{Mn}$ and $\mathrm{Fe}$, but the addition of detrital or volcanic materials results in dilution and enrichment of $\mathrm{Ti}$, $\mathrm{Al}$ and $\mathrm{Zr}$. However, the iron occurrence of the Edea North reveal relatively average values of $\mathrm{Ti}, \mathrm{Al}$ and $\mathrm{Zr}$ which might suggest a low contribution of detrital materials. The correlation coefficients between $\mathrm{Al}_{2} \mathrm{O}_{3}$ and HFSE, LILE and some

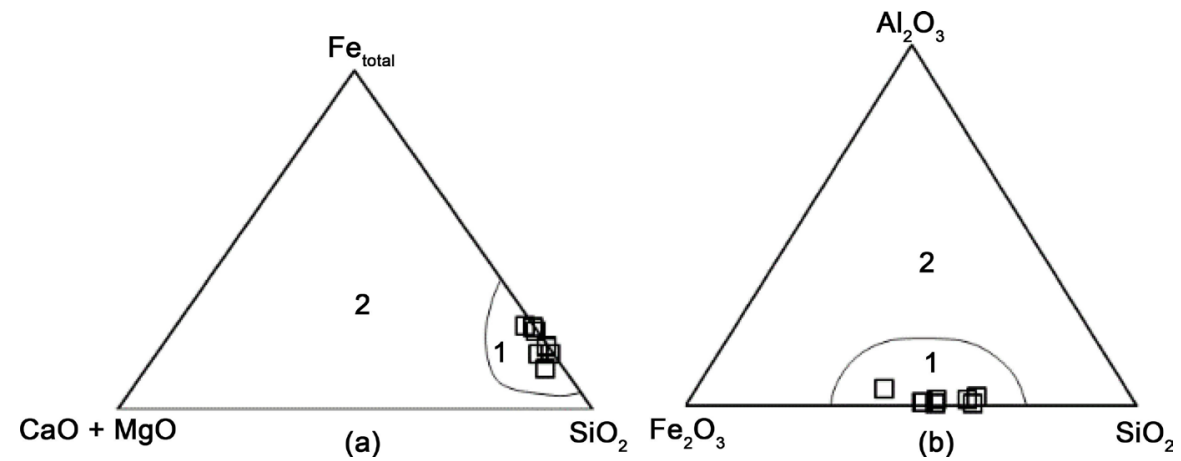

Figure 8. The North of Edéa iron occurrence composition. (a) After [31]. (b) After [30] 1: Precambrian; 2: Post Precambrian. 
transition metals $\mathrm{Zr}(0.82)$, $\mathrm{Hf}$ (0.85), $\mathrm{Rb}(0.44), \mathrm{Sr}$ (0.96), $\mathrm{Cr}(0.70)$ and V (0.99) could also indicate a contribution of clastic materials during the deposition of these formations. The Th/U ratios in these samples range from 1.27 to 6.28 , except for EDN17 where it is higher (29.25). This observation suggests a strong or moderate contamination by phosphates.

\subsection{Origin and Enrichment Processes of the Edea North Iron Occurrence}

Various methods have been used to establish the difference between hydrothermal, biogenic, detrital and seawater sources based on mineralogical, chemical and geochronological differences in the formation of iron deposits [6] [29] [30] [35] [36]. Among these methods, numerous discrimination diagrams have been proposed by several authors to highlight the influence of detrital components, hydrothermalism, biological components and seawater in their genesis [34] [37] [38] [39]. On the $\mathrm{SiO}_{2}$ vs $\mathrm{Al}_{2} \mathrm{O}_{3}$ diagram [34], the iron mineralization samples from the Edea North iron occurrence plot within the hydrothermal domain (Figure 9). In the Fe-Mn-Al ternary diagram [38] the hydrothermal in origin is confirmed (Figure 10). The studied samples plot in the same area as those from the Bikoula BIFs of the Ntem complex [36]. This observation could indicate that $\mathrm{Si}$ and $\mathrm{Fe}$ of the studied deposits derived directly from a hydrothermal source. Similarly, in the $\mathrm{Fe} / \mathrm{Ti}$ vs $\mathrm{Al} /(\mathrm{Al}+\mathrm{Fe}+\mathrm{Mn})$ diagram [37] a high affinity of the samples from the studied site with the hydrothermal domain is highlighted (Figure 11). This suggests an important contribution (in the volume) of the components of hydrothermal origin during the deposition of studied formations. Samples plot close to the field of modern metalliferous sediments indicating that some of the source components of the studied iron occurrence may have derived from sediments rich in highly hydrothermalized metals.

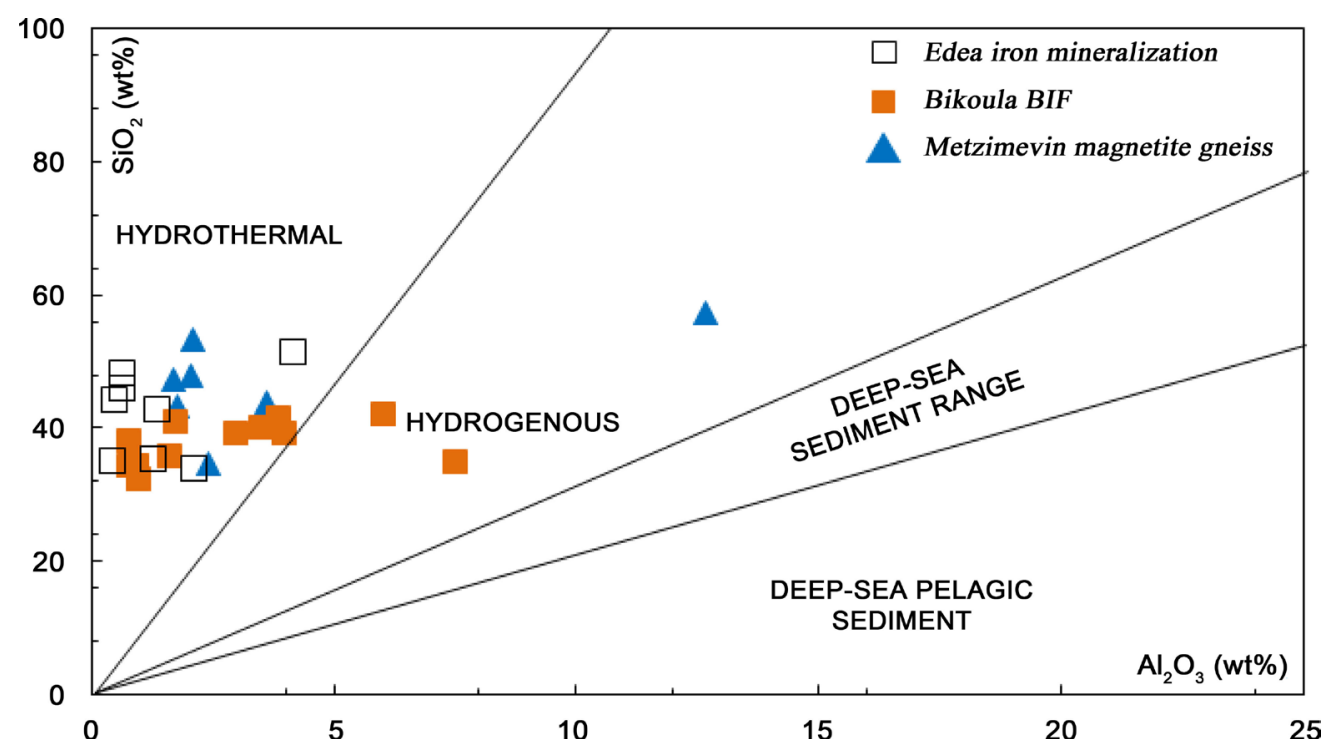

Figure 9. $\mathrm{SiO}_{2}$ vs $\mathrm{Al}_{2} \mathrm{O}_{3}$ discrimination diagram indicating the hydrothermal affinity of the Edea iron mineralization. Note the hydrothermal affinity of Edea north samples; Metzimevin magnetite gneisses after [7] and Bikoula BIF after [36]. 


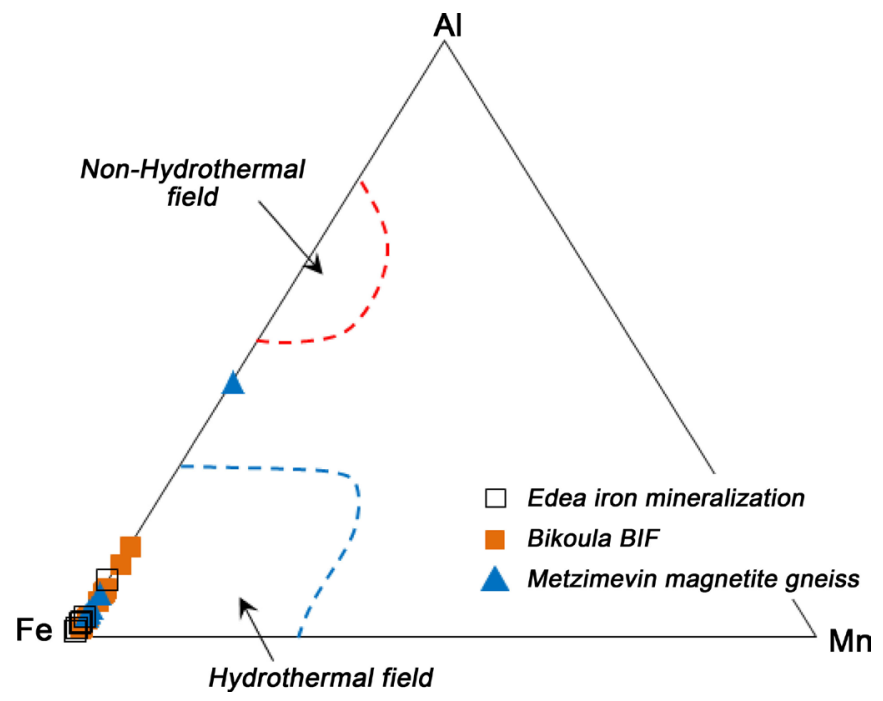

Figure 10. Ternary Fe-Mn-Al diagram indicating the hydrothermal affinity of the Edea North iron mineralization, Metzimevin magnetite gneisses (after [7]) and Bikoula BIF southern Cameroon (after [31]).

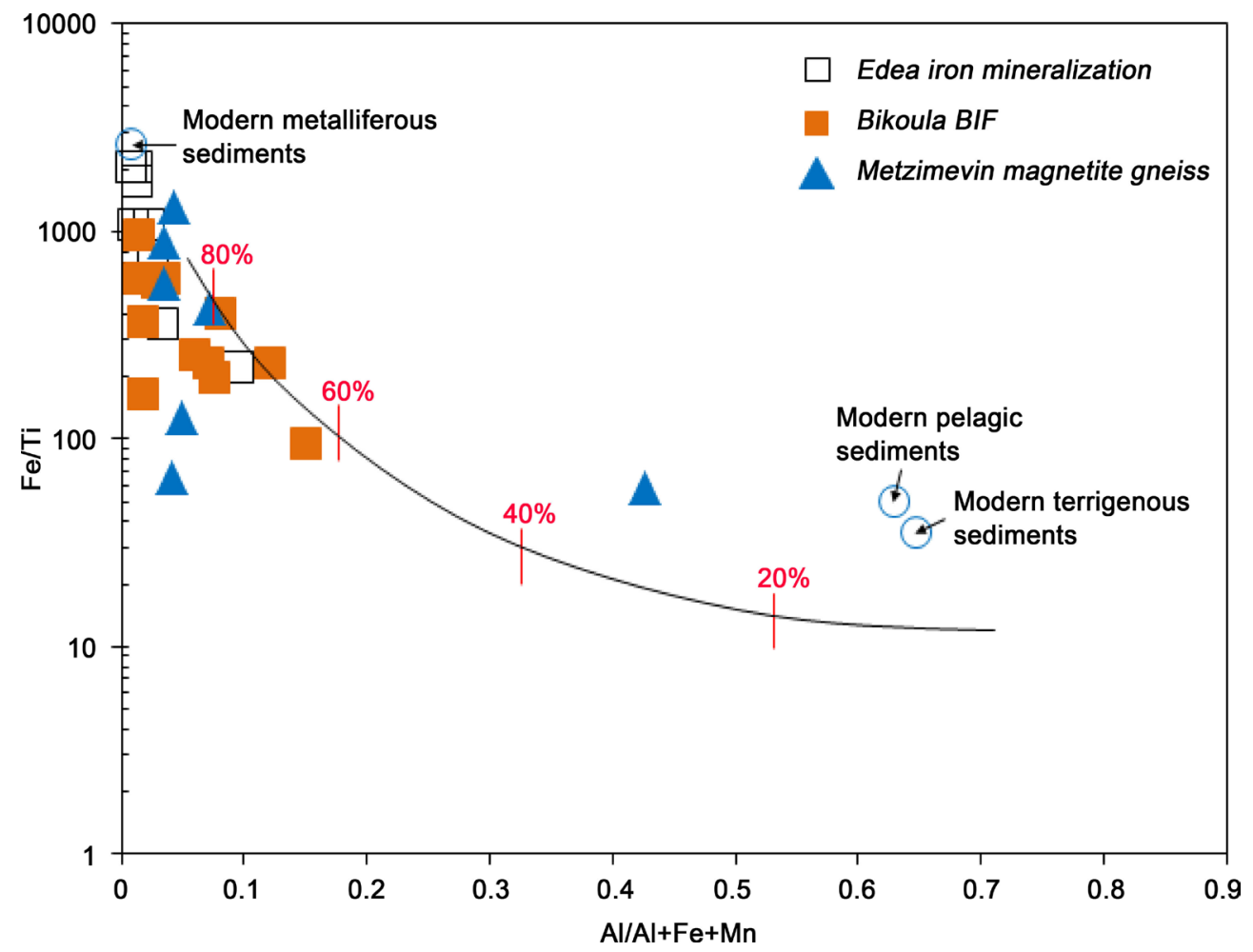

Figure 11. Composition of the Edea north iron occurrence plotted on the $\mathrm{Fe} / \mathrm{Ti}$ vs $\mathrm{Al} /(\mathrm{Al}+\mathrm{Fe}+$ $\mathrm{Mn}$ ) discrimination diagram after [37]. This diagram is proposed to estimate the relative involve of hydrothermal inputs in the fluids during the BIF precipitation.

The hydrothermal predominance is demonstrated particularly in the $\mathrm{Y} / \mathrm{P}_{2} \mathrm{O}_{5}$ vs $\mathrm{Zr} / \mathrm{Cr}$ discrimination diagram after [39] in which all samples have a low $\mathrm{Zr} / \mathrm{Cr}$ and $\mathrm{Y} / \mathrm{P}_{2} \mathrm{O}_{5}$ ratio (Figure 12). The vanadium content in the sediments is generally low when compared to the upper lithosphere [40]. The vanadium content varies between 5 and $69 \mathrm{ppm}$ with an average of $20.5 \mathrm{ppm}$ in the studied rocks 


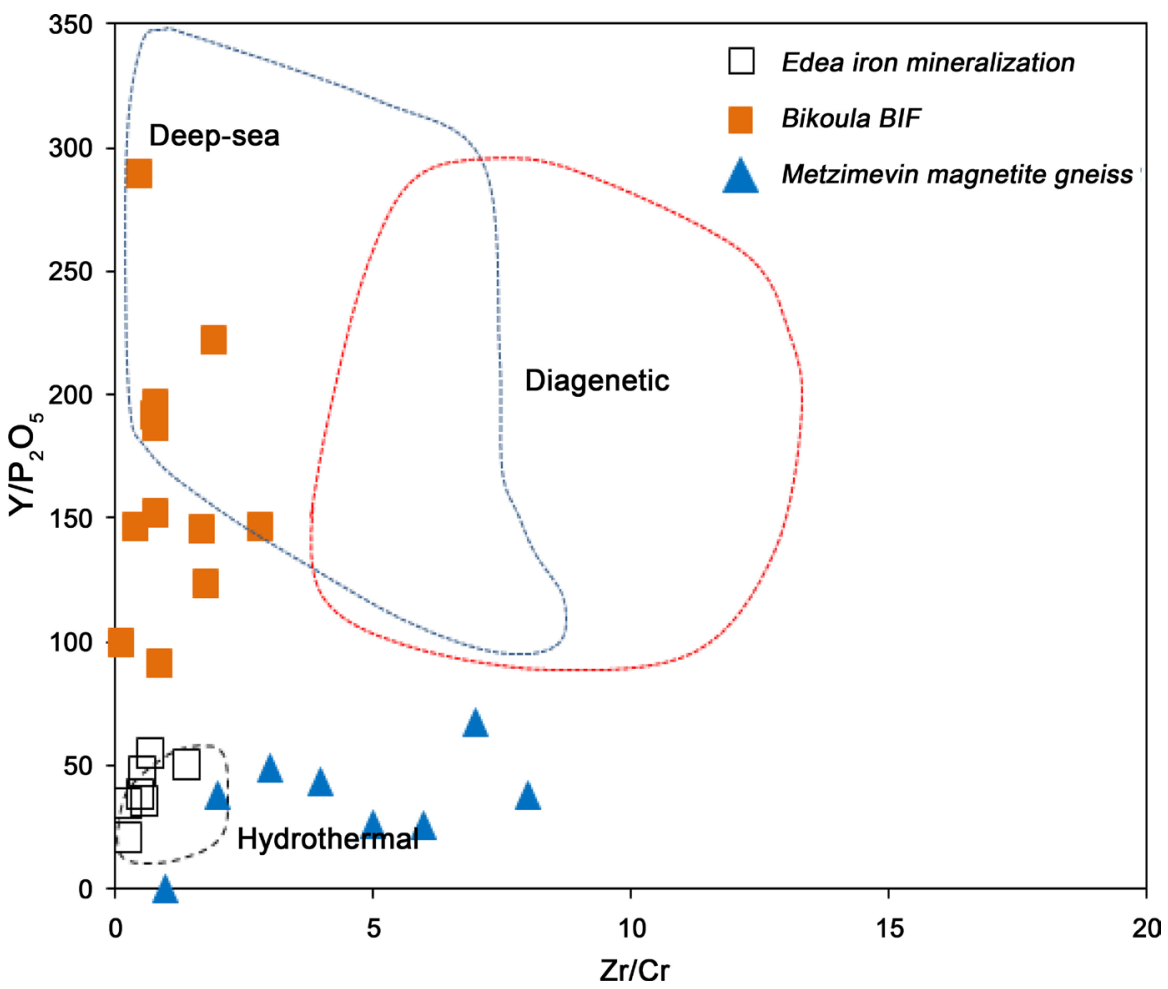

Figure 12. Composition of the Edea north iron mineralization plotted in a bivariate diagram of $\mathrm{Y} / \mathrm{P}_{2} \mathrm{O}_{5}$ vs $\mathrm{Zr} / \mathrm{Cr}$. Deep Sea, diagenetic and metalliferous fields are based on data from [39].

(Table 2). This content is similar to that of deposits in China [41] and higher than BIF from the Ntem complex with values comprise between 9 and $11 \mathrm{ppm}$ [42]. The Clarke value of chromium in sediments is $110 \mathrm{ppm}$ and in igneous rocks from 200 to $2000 \mathrm{ppm}$. The chromium contents in the studied materials is smaller (10 and $80 \mathrm{ppm}$; average of $30 \mathrm{ppm}$ ) than the Clarke value of $\mathrm{Cr}$ in the sediments. Barium, on the other hand, shows concentration values between 1.6 and $131 \mathrm{ppm}$ with an average of $51.17 \mathrm{ppm}$; this is relatively low compared to that of rocks of igneous origin. This content is comparable to sedimentary magnetite quartzites in the Arcot district of India [40]; thus a sedimentary origin can be inferred for the Edea North iron mineralization.

REE are commonly used by several authors to infer the environmental conditions for deposition and origins of iron ore formations [43] [44] [45] [46]. The REE content of the studied formation are relatively higher than REE content from iron formations in Cameroon (see [11] [36]). Chondrite-normalized REE patterns exhibit slight negative anomalies in Eu suggesting a prevalence of an oxidizing depositional environment during the Archean period [47]. The influence of the heterogeneous imprint of the clastic materials in the deposition basin could explain the negative $\mathrm{Eu}$ anomalies presented by most of the samples from this occurrence [48] [36]. Positive Eu anomalies represented by $\mathrm{Eu} / \mathrm{Eu}^{*}$ with values between 1 and 1.83 demonstrates the contribution of deep-sea hydrothermal solutions [6] [49] [50]. Some of the samples show negative Ce anomalies (Figure 7). These negative anomalies suggest the influence of sea water into the system [51]. 


\section{Conclusion}

The origin and enrichment process of iron mineralization in Edea North are constraint by the coupling of petrographic and geochemistry analyses. The results obtained show that magnetite and quartz are the common predominant minerals while pyroxene and amphibole are secondary minerals. Base on this mineralogical composition, the studied rocks have been referred to as magnetite quartzite. In this occurrence, magnetite occurs in two textural varieties including irregular and elongated minerals blasts and finally xenomorphic in the silicate phase. The dominating chemical components of the studied materials are. A sedimentary origin with a high contribution of hydrothermal fluids and low input of detrital materials has been suggested for the Edea North iron occurrence.

\section{Acknowledgements}

This paper is a part of a Ph.D thesis by the first author, at the University of Douala (Cameroon). We appreciate support from "Laboratoire de Propriétés des amorphes, liquides et minéraux de l'institut de physique des matériaux et de cosmochimie de l'Université de Pierre et Marie Curie (France)" for thin section preparation and EMPA analysis. C.E. Suh is thanked for his diligent assistance with the petrographic investigations.

\section{References}

[1] Gross, G.A. (1983) Iron-Formation in Fold Belts Marginal to the Ungava Craton. In: Trendall, A.F. and Morris, R.C., Eds., Iron Formation: Facts and Problems, Elsevier, Amsterdam, 253-294.

[2] James, H.J. (1954) Sedimentary Facies of Iron Formation. Economic Geology, 49, 235-293. https://doi.org/10.2113/gsecongeo.49.3.235

[3] Planavsky, N., Bekker, A., Rouxel, O.J., Kamber, B., Hofmann, A., Knudsen, A. and Lyons, W.T. (2010) Rare Earth Element and Yttrium Compositions of Archaean and Paleoproterozoic Fe Formations Revisited: New Perspectives on the Significance and Mechanisms of Deposition. Geochimica et Cosmochimica Acta, 74, 63876405.

[4] Suh, C.E., Cabral, A.R., Shemang, E.M., Mbinkar, L. and Mboudou, G.G.M. (2008) Two Contrasting Iron-Ore Deposits in the Precambrian Mineral Belt of Cameronn, West Africa. Exploration and Mining Geology, 17, 197-207. https://doi.org/10.2113/gsemg.17.3-4.197

[5] Chombong, N.N. and Suh, C.E. (2013) 2883 Ma Commencement of BIF Deposition at the Northern Edge of Congo Craton, Southern Cameroon: New Zircon SHRIMP Data Constraint from Metavolcanics. Episodes, 36, 47-57.

[6] Ilouga, C., Suh, C.E. and Tanwi, G.R. (2013) Textures and Rare Earth Elements Composition of Banded Iron Formations (BIF) at Njweng Prospect, Mbalam Iron Ore District, Southern Cameroon. International Journal of Geosciences, 4, 146-165. https://doi.org/10.4236/ijg.2013.41014

[7] Chombong, N. (2013) Petrochemistry and SHRIMP U-Pb Geochronology of Banded Iron Formation, Intercalated Volcanics and Metasediments in South Eastern Cameroon. Ph.D. Thesis, University of Buea, Cameroon, $130 \mathrm{p}$.

[8] Kelvin, F.E.A., Wall, F., Gavyn, K.R. and Moon, C.J. (2014) Quantitative Minera- 
logical and Chemical Assessment of the Nkout Iron Ore Deposit, Southern Cameroon. Ore Geology Reviews, 64, 25-39.

[9] Suh, C.E., Cabral, A.R. and Ndime, E. (2009) Geology and Ore Fabrics of the Nkout High-Grade Hematite Deposit, Southern Cameroon. In: Williams, P.J., et al., Eds., Smart Science for Exploration and Mining, SGA Publication Series, Amsterdam, 558-560.

[10] Ganno, S., Ngnotue, T., Kouankap, N.G.D., Nzenti, J.P. and Notsa, F.M. (2015) Petrology and Geochemistry of the Banded Iron-Formations from Ntem Complex Greenstones Belt, Elom Area, Southern Cameroon: Implications for the Origin and Depositional Environment. Chemie der Erde, 75, 375-387.

[11] Ganno, S., Moudioh, C., Nzina Nchare, A., Kouankap Nono, G.D. and Nzenti, J.P. (2015) Geochemical Fingerprint and Iron Ore Potential of the Siliceous Itabirite from Palaeoproterozoic Nyong Series, Zambi Area, Southwestern Cameroon. Resource Geology, 66, 71-80.

[12] Ganno S., Njiosseu, T.E.L., Kouankap, N.G.D., Djoukouo, S.A., Moudioh, C., Ngnotué, T. and Nzenti, J.P. (2017) A Mixed Seawater and Hydrothermal Origin of Superior-Type Banded Iron Formation (BIF)-Hosted Kouambo Iron Deposit, Palaeoproterozoic Nyong Series, Southwestern Cameroon: Constraints from Petrography and Geochemistry. Ore Geology Reviews, 80, 860-875.

[13] Maurizot, P., Abessolo, A., Feybesse, J.L., Johan, V. and Lecomte, P. (1986) Etude et prospection minière du Sud-Ouest Cameroun. Synthèse des travaux de 1978 à 1985. BRGM Report 85 CMR 066.

[14] Nédélec, A., Nsifa, E.N. and Martin, H. (1990) Major and Trace Element Geochemistry of the Achaean Ntem Plutonic Complex (South Cameroon): Petrogenesis and Crustal Evolution. Precambrian Research, 47, 35-50.

[15] Goodwin, A.M. (1991) Precambrian Geology. The Dynamic Evolution of the Continental Crust. Academic Press, Great Britain, 666 p.

[16] Nzenti, J.P., Barbey, P., Macaudière, J. and Soba, D. (1988) Origin and Evolution of the Late Precambrian High-Grade Yaounde Gneisses (Cameroon). Precambrian Research, 38, 91-109.

[17] Shang, C.K., Liegeois, J.P., Satir, M., Frisch, W. and Nsifa, E.N. (2010) Late Archean High-K Granite Geochronology of the Northern Metacratonic Margin of the Archaean Congo Craton, Southern Cameroon: Evidence for Pb-Loss Due to NonMetamorphic Causes. Gondwana Research, 18, 337-355.

[18] Shang, C.K., Siebel, W., Satir, M., Chen, F. and Mvondo, J.O. (2004) Zircon Pb-Pb and U-Pb Systematic of TTG Rocks in the Congo Craton: Constraints on Crust Formation, Magmatism and Pan-African Lead Loss. Bulletin of Geoscience, 79, 205-219.

[19] Tchameni, R., Mezger, K. and Nsifa, E.N. (1996) Geochemical and Nd-Sr Isotope Composition of the Archaean Ntem Granitoids (Southern-Cameroon): Evidence for Rapid Crustal Growth. Journal Conference Abstracts, 616.

[20] Shang, C.K., Satir, M., Nsifa, E.N., Liegeois, J.P., Siebel, W. and Taubald, H. (2007) Archean High K-granitoids Produced by Remelting of Early Tonalite-Trondhjemite-Granodiorite (TTG) in the Sangmelima Region of Ntem Complex of Congo Craton, Southern Cameroon. International Journal of Earth Sciences, 96, 817-841. https://doi.org/10.1007/s00531-006-0141-3

[21] Tchameni, R., Mezger, K., Nsifa, N.E. and Pouclet, A. (2001) Crustal Origin of Early Proterozoic Syenites in the Congo Craton (Ntem Complex), Southern Cameroon. Journal of African Earth Sciences, 30, 133-147.

[22] Toteu, S.F., Van Schmus, W.R., Penaye, J. and Nyobé, J.B. (1994) U-Pb and Sm-Nd 
Evidence for Eburnean and Pan-African High-Grade Metamorphism in Cratonic Rocks of Southern Cameroon. Precambrian Research, 67, 321-347.

[23] Lerouge, C., Cocherie, A., Toteu, S.F., Penaye, J., Milési, J.P., Tchameni, R., Nsifa, E.N., Fanning, C.M. and Deloule, E. (2006) Shrimp U-Pb Zircon Age Evidence for Paleoproterozoic Sedimentation and 2.05 Ga Syntectonic Plutonism in the Nyong Group, South-Western Cameroon: Consequences for the Eburnean-Transamazonian Belt of NE Brazil and Central Africa. Journal of African Earth Sciences, 44, 413-427.

[24] Ndema Mbongue, J.L., Ngnotue, T., Ngo Nlend, C.D., Nzenti, J.P. and Cheo Suh, E. (2014) Origin and Evolution of the Formation of the Cameroon Nyong Series in the Western Border of the Congo Craton. Journal of Geosciences and Geomatics, 2, 62- 75.

[25] Feybesse, J.L., Johan, V., Triboulet, C., Guerrot, C., Mayaga-Mikolo, F., Bouchot, V. and Eko N'dong, J. (1998) The West Central African Belt: A Model of 2.5-2.0 Ga Accretion and Two-Phase Orogenic Evolution. Precambrian Research, 87, 161-216.

[26] Owona, S. (2008) Archaean, Eburnean and Pan-African Features and Relationships in Their Junction Zone in the South of Yaoundé (Cameroon). Ph.D. Thesis, University of Douala, Cameroon, $232 \mathrm{p}$.

[27] Nsangou, N.M., Owona, S., Youmen, D., Mpesse, J.E., Tckecke, M.F., Temfack, M., Ganwa, A.A., Joseph, M.O., Lothar, R. and Ekodeck, G.E. (2013) Contrôle géologique des unités morphotectoniques de la région d'Edéa Eséka (SW Cameroun). Revue du Conseil Africain Malgache pour l'Enseignement Supérieur, 1, 8 p.

[28] Taylor, S.R. and McLennan, S.M. (1985) The Continental Crust, Its Composition and Evolution. Blackwell Scientific Publications, Oxford.

[29] Klein, C. (2005) Some Precambrian Banded Iron-Formations (BIFs) from Around the World: Their Age, Geologic Setting, Mineralogy, Metamorphism, Geochemistry, and Origins. American Mineralogist, 90, 1473-1499. https://doi.org/10.2138/am.2005.1871

[30] Lepp, H. and Goldich, S.S. (1964) Origin of the Precambrian Iron-Formation. Economic Geology, 59, 1025-1060. https://doi.org/10.2113/gsecongeo.59.6.1025

[31] Govett, G.J.S. (1966) Origin of Banded Iron-Formation. Geological Society of America Bulletin, 77, 1191-1212. https://doi.org/10.1130/0016-7606(1966)77[1191:OOBIF]2.0.CO;2

[32] Craig, J.R. and Vaughan, D.J. (1994) Ore Microscopy and Ore Petrography. 2nd Edition, John Wiley \& Sons Inc., Hoboken, 424.

[33] Bolhar, R., Kamber, B.S., Moorbath, S., Fedo, C.M. and Whitehouse, M.J. (2004) Characterisation of Early Archaean Chemical Sediment by Trace Element Signatures. Earth and Planetary Science Letters, 222, 43-60.

[34] Bonatti, E. (1975) Metallogenesis at Oceanic Spreading Centers. Annual Review of Earth and Planetary Sciences, 3, 401-431. https://doi.org/10.1146/annurev.ea.03.050175.002153

[35] Lacelles, D.F. (2006) Black Smokers and Density Currents: A Uniformitarian Model for the Genesis of Banded Iron-Formations. Ore Geology Reviews, 32, 381-411.

[36] Tessontsap, T., Tomaso, R.R.B., Paul-Désiré, N., Johannes, C.V., Damon, T., Matthew, C. and Derek, V. (2016) Petrography and Geochemistry of the Mesoarchean Bikoula Banded Iron Formation in the Ntem complex (Congo Craton), Southern Cameroon: Implications for Its Origin. Ore Geology Reviews, 80, 267-288.

[37] Bostrom, K. (1973) The Origin and Fate of Ferromanganoan Active Ridge Sediments. Stockholm Contributions in Geolog, 27, 149-243.

[38] Bonatti, E., Kolla, V., Moore, W.S. and Stern, C. (1979) Metallogenesis in Marginal 
Basins: Fe-Rich Basal Deposits from the Philippine. Marine Geology, 32, 21-37.

[39] Marchig, V., Gundlach, H., Möller, P. and Schley, F. (1982) Some Geochemical Indicators for Discrimination between Diagenetic and Hydrothermal Metalliferous Sediments. Marine Geology, 50, 241-256.

[40] Raghu, B.K., Sudarsana, R.G., Keshava, K.P.L. and Gangi, R.S. (2013) Petroche- mistry and Genesis of Banded Iron Formation (BIF), a Study from North Arcot District, Tamilnadu, India. International Journal of Geology, 3, 213-232.

[41] Yang, X., Liu, L., Lee, I., Wang, B., Du, Z., Wang, Q., Wang, Y. and Sun, W. (2014) A Review on the Huoqiu Banded Iron Formation (BIF), Southeast Margin of the North China Craton: Genesis of Iron Deposits and Implications for Exploration. Ore Geology Reviews, 63, 418-443.

[42] Chombong, N., Suh, C.E. and Ilouga, C. (2013) New Detrital Zircon U-Pb Ages from BIF-Related Metasediments in the Ntem Complex (Congo Craton) of Southern Cameroun, West Africa. Natural Science, 5, 835-847. https://doi.org/10.4236/ns.2013.57101

[43] Bau, M. and Dulski, P. (1996) Distribution of Yttrium and Rare-Earth Elements in the Penge and Kuruman Iron Formation, Transvaal Supergroup, South Africa. Precambrian Research, 79, 37-55.

[44] Frei, R., Dahl, P.S., Duke, E.F., Frei, K.M., Hansen, T.R., Frandsson, M.M. and Jensen, L.A. (2008) Trace Element and Isotopic Characterization of Neoarchean and Paleoproterozoic Iron Formations in the Black Hills (South Dakota USA): Assessment of Chemical Change during 2.9-1.9 Ga Deposition Bracketing the 2.4-2.2 Ga First Rise of Atmospheric Oxygen. Precambrian Research, 162, 441-474.

[45] Bao, S.-X., Zhou, H.-Y., Peng, X.-T., Ji, F.-W. and Yao, H.-Q. (2008) Geochemistry of REE and Yttrium in Hydrothermal Fluids from the Endeavour Segment, Juan de Fuca Ridge. Geochemical Journal, 42, 359-370. https://doi.org/10.2343/geochemj.42.359

[46] Alkmim, A.R., Sampaio, G.M.S., Dantas, J.C.M., de Abreu, A.T. and Nalini Jr., H.A. (2015) Geochemical Fingerprint of Siliceous, Amphibolitic and Magnetitic Itabirite Types of the Region of Serra Azul-Quadrilátero Ferrífero, MG. Rem: Revista Escola de Minas, 68, 037-042. https://doi.org/10.1590/0370-44672015680104

[47] Janardhan, A.S., Sadhakshara, S.N. and Capdevila, R.J. (1986) Banded Iron Formations and Associated Mangniferrous Horizons of Sargur Supra Crustals, South Karnataka. Journal of Geological Society of India, 28, 129-180.

[48] Arora, M., Govil, P., Charan, S., Uday Raj, B., Balaram, V., Manikyamba, C., Chatterjee, A. and Naqvi, S. (1995) Geochemistry and Origin of Archean Banded Iron Formation from Babadudan Belt, India. Economic Geology, 90, 2040-2057. https://doi.org/10.2113/gsecongeo.90.7.2040

[49] Dymek, R.F. and Klein, C. (1988) Chemistry, Petrology and Origin of Banded Iron-Formation Lithologies from the 3800 MA Isua Supracrustal Belt, West Greenland. Precambrian Research, 39, 247-302.

[50] Klein, C. and Beukes, N.J. (1992) Time Distribution, Stratigraphy and Sedimentologic Setting and Geochemistry of Precambrian Iron Formation. In: Schopf, J.W. and Klein, C., Eds. The Proterozoic Biosphere: A Multidisciplinary Study, Cambridge University Press, New York, 139-146.

[51] De Baar, H.J.W., Bacon, P.M., Brewer, P.G. and Bruland, K.W. (1985) Rare Earth Elements in the Pacific and Atlantic Oceans. Geochimica et Cosmochimica Acta, 49, 1943-1959. 
Submit or recommend next manuscript to SCIRP and we will provide best service for you:

Accepting pre-submission inquiries through Email, Facebook, LinkedIn, Twitter, etc. A wide selection of journals (inclusive of 9 subjects, more than 200 journals)

Providing 24-hour high-quality service

User-friendly online submission system

Fair and swift peer-review system

Efficient typesetting and proofreading procedure

Display of the result of downloads and visits, as well as the number of cited articles Maximum dissemination of your research work

Submit your manuscript at: http://papersubmission.scirp.org/

Or contact ijg@scirp.org 